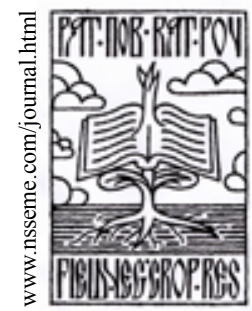

\title{
Nitrogen Accumulation in Lucerne (Medicago sativa L.) Under Water Deficit Stress
}

\author{
Viliana Vasileva • Emil Vasilev
}

\author{
received: 21 February 2013, revised: 29 April 2013, accepted: 21 May 2013 \\ published online: 28 May 2013 \\ (c) 2013 IFVC \\ doi: 10.5937/ratpov50-3407
}

\begin{abstract}
Summary: In order to study nitrogen accumulation in aboveground and root dry mass in lucerne (Medicago sativa L.) under water deficit stress, a pot experiment was carried out at the Institute of Forage Crops, Pleven, Bulgaria. The plants were grown under optimum water supply (75-80\% FC) and 10-days water deficit stress was simulated at the stage of budding by interrupting the irrigation until soil moisture was reduced to 37-40\% FC. Mineral nitrogen fertilization (ammonium nitrate) at the doses of 40, 80, 120 and $160 \mathrm{mg} \mathrm{N} \mathrm{kg}^{-1}$ soil was applied. It was found that nitrogen accumulation in dry aboveground mass was reduced to $18.0 \%$, and in dry root mass to $26.5 \%$ under water deficit stress. Mineral nitrogen fertilization contributed to easily overcome the stress conditions of water deficit stress in lucerne.

Key words: accumulation, fertilization, lucerne, nitrogen, soil water deficit
\end{abstract}

\section{Introduction}

Lucerne (Medicago sativa L.) is a nitrogen-fixing crop with a capability to accumulate significantly more nitrogen in their biomass (Jarvis 2005). The application of additional nitrogen is debatable in the literature due to its nitrogen-fixing ability (Oliveira et al. 2004, Werner \& Newton 2005). Unfavourable factors limit multiplication frequently. Although potential to tolerate acute conditions of water deficit stress (Busse \& Bottomley 1989, Solanki \& Patel 2000), due to the deeper root system, seed yield in lucerne is considerably influenced by lack of moisture (Shock et al. 1989, 2001, Frame et al. 1998) and decreased from 18 to $33 \%$ (Vasileva et al. 2006). Because of greater necessity of $C$ and $N$ assimilates during the reproductive stage nitrogen accumulation is an important indicator and one of the limiting factors for plant growth and seed yield formation (Serraj at el. 1999). The aim of this work was to study nitrogen accumulation in lucerne under water deficit stress.

V. Vasileva* • E. Vasilev

Institute of Forage Crops, 89 Gen. Vl. Vazov Str., Pleven 5800, Bulgaria

e-mail: viliana.vasileva@gmail.com

\section{Materials and Methods}

A pot experiment was carried out on lucerne (Medicago sativa $\mathrm{L}$.) $\mathrm{cv}$. Victoria at the Institute of Forage Crops, Pleven, Bulgaria (2003-2004). Soil subtype of leached chernozem was filled in $10 \mathrm{~L}$ pots. The following treatments were tested with four replications: Under optimum water supply $-75-80 \%$ of field capacity (FC): 1 . Control 1 - unfertilized NOPK - (C1); 2. Soil + $40 \mathrm{mg}$ $\mathrm{N} \mathrm{kg}^{-1}$ soil (N40PK); 3. Soil $+80 \mathrm{mg} \mathrm{N} \mathrm{kg}^{-1}$ soil (N80PK); 4. Soil + $120 \mathrm{mg} \mathrm{N} \mathrm{kg}^{-1}$ soil (N120PK); 5. Soil + $160 \mathrm{mg} \mathrm{N} \mathrm{kg}^{-1}$ soil (N160PK). Under 10day water deficit stress (37-40\% FC): 6. Control 2 - unfertilized- NOPK (C2); 7. Soil + $40 \mathrm{mg} \mathrm{N} \mathrm{kg}^{-1}$ soil (N40PK); 8 . Soil + $80 \mathrm{mg} \mathrm{N} \mathrm{kg}^{-1}$ soil (N80PK); 9. Soil + $120 \mathrm{mg} \mathrm{N} \mathrm{kg}^{1}$ soil (N120PK); 10. Soil + $160 \mathrm{mg} \mathrm{N} \mathrm{kg}^{-1}$ soil (N160PK). Mineral nitrogen as ammonium nitrate equivalent to the tested doses was applied. All treatments were treated against a background of $\mathrm{P}$ and $\mathrm{K}$, the phosphorus being applied as triple super phosphate, and potassium as potassium chloride. For treatments 1-5 the plants were maintained at $75-80 \% \mathrm{FC}$, and for 6-10 water deficit stress was simulated at the budding stage by interrupting the irrigation until reducing the soil moisture down to $37-40 \%$ FC. 
Samples were taken when lucerne was harvested for seeds. Dry aboveground mass and dry root mass were recorded (dried at $60^{\circ} \mathrm{C}$ ). Nitrogen in aboveground and root dry mass was calculated as a product of aboveground and root dry mass yield and total nitrogen content (determined by standard Kjeldahl method in dry mass) (Nelson \& Sommers 1980). Total nitrogen accumulation was calculated as the sum of that in aboveground and root mass. Reduction in percentage of nitrogen accumulation after water deficit stress was determined using the following formula:
Doses of 40 and $80 \mathrm{mg} \mathrm{N} \mathrm{kg}^{-1}$ soil did not significantly affect nitrogen accumulation in dry aboveground mass under water deficit stress. For doses of 120 and $160 \mathrm{mg} \mathrm{N} \mathrm{kg}^{-1}$ soil there was an increase in nitrogen accumulation as compared to unfertilized control by 6.1 and $13.8 \%$, respectively.

Nitrogen accumulation in dry root mass decreased to $35.1 \%$ with increase of doses of mineral nitrogen fertilization under optimum water supply (Table 2). It is related to the directing of assimilates to leaf mass and needs of nitrogen

Reduction in $\mathrm{N}$ accumulation $(\%)=\quad \begin{array}{cc}\mathrm{N} \text { accumulation in control }-\mathrm{N} \text { accumulation after nitrogen } \\ \text { fertilization }\end{array} \times 100$

The data were statistically processed by the LSD using SPSS 10.0 computer program.

\section{Results and Discussion}

Lucerne used soil or fertilizer nitrogen, since nitrogen assimilation required lower rates of $\mathrm{CO}_{2}$ and energy than nitrogen fixation in starting development (Hartwig \& Soussana 2001). This reflects on the nitrogen accumulation in plants.

In our study nitrogen accumulation in dry aboveground mass under optimum water supply increased with the increase of doses of mineral nitrogen fertilization (Table 1). For the experimental doses of 40 and $80 \mathrm{mg} \mathrm{N} \mathrm{kg}^{-1}$ soil, the increase as compared to unfertilized control was by 6.7 and $9.5 \%$ and for the doses of 120 and $160 \mathrm{mg} \mathrm{N} \mathrm{kg}^{-1}$ soil by 22.3 and $24.2 \%$, respectively. for seeds with high protein content (Tufenkci et al. 2006).

Under the conditions of water deficit stress for the doses of 120 and $160 \mathrm{mg} \mathrm{N} \mathrm{kg}^{-1}$ soil, nitrogen in dry root mass decreased by 24.9 and $30.7 \%$, respectively.

Our results showed that plants insured with nitrogen easily overcome water deficit stress. In confirmation of that are the findings of Radeva (1991) and Antolin et al. (1995) according to which lucerne plants fertilized with mineral nitrogen and subjected to water deficit stress showed better growth and productivity as compared to these depend only on the nitrogen of symbiotic $\mathrm{N}_{2}$ fixation. Nitrogen is important for growth and formation of seeds with high protein content and water deficit affects supply of plants with nitrogen.

Table 1. Nitrogen accumulation in dry aboveground mass in lucerne

\begin{tabular}{lcc}
\hline Treatments & $\begin{array}{c}\text { Optimal water supply } \\
(75-80 \% \text { FC })\end{array}$ & $\begin{array}{c}\text { Water deficit stress } \\
(37-40 \% \text { FC })\end{array}$ \\
\hline N0PK $(\mathrm{C} 1)$ & 591.3 & 558.7 \\
N40PK & 631.2 & 543.6 \\
N80PK & 647.3 & 574.2 \\
N120PK & 722.9 & 592.8 \\
N160PK & 734.3 & 635.6 \\
Average & 665.4 & 581.0 \\
LSD at $\mathrm{P}<0.05$ & 25.8 & 16.2 \\
\hline
\end{tabular}


Table 2. Nitrogen accumulation in dry root mass in lucerne

\begin{tabular}{lcc}
\hline Treatments & $\begin{array}{c}\text { Optimal water supply } \\
(75-80 \% \mathrm{FC})\end{array}$ & $\begin{array}{c}\text { Water deficit stress } \\
(37-40 \% \mathrm{FC})\end{array}$ \\
\hline N0PK $(\mathrm{C} 1)$ & 357.9 & 274.6 \\
N40PK & 360.7 & 265.0 \\
N80PK & 307.8 & 267.7 \\
N120PK & 245.6 & 206.3 \\
N160PK & 232.4 & 190.2 \\
Average & 300.9 & 240.8 \\
LSD at P $<0.05$ & 25.5 & 17.1 \\
\hline
\end{tabular}

Total nitrogen accumulation ( $\mathrm{N}$ in dry aboveground $+\mathrm{N}$ in dry root mass) varied in narrow range and was less affected by mineral nitrogen fertilization under both conditions of water supply (Figure 1).

Although lucerne is more tolerant than most of forage legumes, some characteristics like nitrogen in yield are influenced negatively by the water deficit stress (Serraj et al. 1999, Zahran 1999, 2001, Humphries \& Auricht 2001). Root mass of the plants was more sensitive to water deficit stress as compared to aboveground mass. Nitrogen accumulation in dry aboveground mass decreased to $18.0 \%$, but in dry root mass to $26.5 \%$ (Table 3).

Some authors (Cihacek 1994, Petkova 1994) consider lucerne needs nitrogen despite its nitrogen-fixing ability. This is particularly true for the stress conditions of water deficit. Water deficit stress strongly reduced nitrogen in dry root mass in the plants of unfertilized control (by 23.3\%). The decrease for doses of 80 and $120 \mathrm{mg} \mathrm{N} \mathrm{kg}^{-1}$ soil was 13.0 and $16.0 \%$, respectively. Under experimental doses of 80 and $120 \mathrm{mg} \mathrm{N} \mathrm{kg}^{-1}$ soil lucerne showed a slightly overcome the negative effect of water

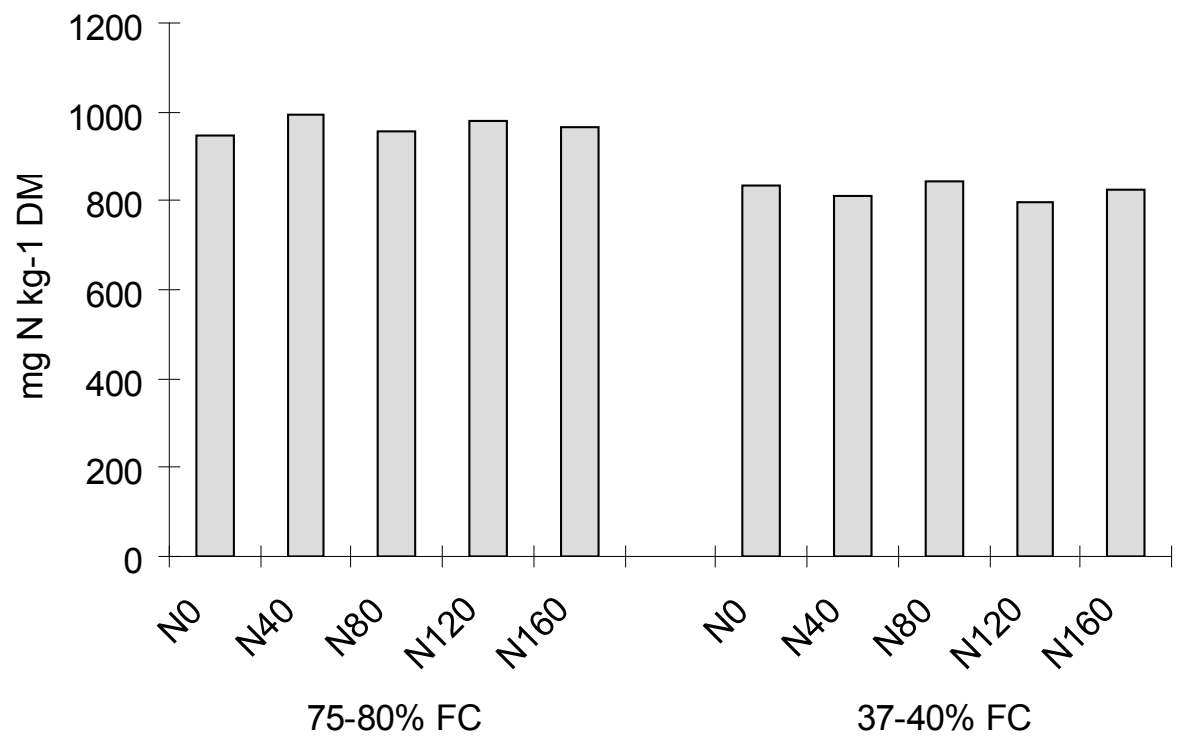

Figure 1. Total nitrogen accumulation in lucerne under optimum water supply (75-80\% FC) and water deficit stress $(37-40 \% \mathrm{FC})$ 
Table 3. Percent of reduction in nitrogen in dry mass yield in lucerne after water deficit stress

\begin{tabular}{lccc}
\hline Treatments & \multicolumn{3}{c}{ Nitrogen in yield (\%) } \\
\cline { 2 - 4 } & $\begin{array}{c}\text { Aboveground } \\
\text { dry mass }\end{array}$ & $\begin{array}{c}\text { Root } \\
\text { dry mass }\end{array}$ & $\begin{array}{c}\text { Total (aboveground + root } \\
\text { dry mass) }\end{array}$ \\
\hline N0PK $(\mathrm{C} 1)$ & 5.5 & 23.3 & 12.2 \\
N40PK & 13.9 & 26.5 & 18.5 \\
N80PK & 11.3 & 13.0 & 11.9 \\
N120PK & 18.0 & 16.0 & 18.5 \\
N160PK & 13.4 & 18.2 & 14.6 \\
\hline
\end{tabular}

deficit stress in terms of nodulation and dry root mass (Vasileva 2010). Water deficit stress reduced total nitrogen accumulation $(\mathrm{N}$ in dry aboveground $+\mathrm{N}$ in dry root mass). This decrease was lowest $(11.9 \%)$ in treatment subjected to $80 \mathrm{mg} \mathrm{N} \mathrm{kg}^{-1}$ soil.

\section{Conclusions}

Water deficit stress decreased nitrogen in dry aboveground mass to $18.0 \%$ and nitrogen in dry root mass to $26.5 \%$. Mineral nitrogen fertilization at a dose of $80 \mathrm{mg} \mathrm{N} \mathrm{kg}^{-1}$ soil contributed to easily overcome the stress conditions of water deficit in lucerne.

\section{References}

Antolin, M., Yoller, J., \& Sanchez-Diaz, M. (1995). Effects of temporary drought on nitrate-fed and nitrogen-fixing alfalfa plants. Plant Science, 107,159165.

Busse, M. D., \& Bottomley, P. J. (1989). Growth and nodulation responses of Rhizobium meliloti to water stress induced by permeating and non-permeating solutes. Applied and Environmental Microbiology, 55, 2431-2436.

Cihacek, L.J. (1994). Alfalfa nutrient needs and fertilization. In: Workshop Sobre O Potencial Forrageiro Da Alfafa (Medicago sativa L.) Nos Trópicos, Juiz de Fora, Anais. Juiz de Fora: EMBRAPA, CNPGL, 93-97.

Frame, J. J., Charlton, J. F., \& Laidlow, A. S. (1998). Temperate Forage Legumes. CAB International, pp. $107-$ 159.

Hartwig, U. A., \& Soussana, J. F. (2001). Ecophisiology of symbiotic $\mathrm{N}_{2}$ fixation in grassland legumes. In J. Isselstein, G. Spatz, M. Hofmann (eds.). Organic Grassland Farming. Grassland Science in Europe 6: 23-26.
Humphries, A., \& Auricht G. (2001). Breeding lucerne for Australia's southern dryland cropping environments. Australian Journal Agricultural Research 52:153-169.

Jarvis, S. C. (2005). N flow and N efficiency in legumes based systems: a system overview. In Sward dynamics, N-flows and Forage Utilization in Legume-Based Systems, Proc. of the $2^{\text {nd }}$ COST 852 workshop, Grado, Italy 10-12 November 2005, Wachendorf M., Helgadottir A., Parente G. (eds.), 187-198.

Nelson, D.W., \& Sommers, L. E. (1980). Determination of total nitrogen in plant material. Agronomy Journal, 65, 109-112.

Oliveira, W., Oliveira, P., Corsi, M., Duarte, F., \& Tsai, S. M. (2004). Alfalfa yield and quality as function of nitrogen fertilization and symbiosis with Sinorbizobium meliloti. Scientia Agricola (Piracicaba, Braz.), 61, 433-438.

Petkova, D. (1994). Effect of the fertilization with nitrogen and some microelements on the productivity during the first year of alfalfa grown for seeds. Plant Science, 31(5-6), 33-37. (In Bg)

Radeva, V. (1991). Biological reaction of lucerne varieties under the conditions of different water and nutritive regime. Proceedings of the Eucarpia, September 11-13, Kompolt, Hungary, 256-269.

Serraj, R., Sinclair, T., \& Purcell, L. (1999). Symbiotic $\mathrm{N}_{2}$ fixation response to drought. Journal of Experimental Botany, 50, 143-155.

Shock, C.C., Feibert, E. Pettet, F., Sadowski, A., \& Saunders, M. (2001). Relationship between water stress and seed yield of two drip-irrigated alfalfa varieties. Oregon State University Agricultural Experiment Station, Special Report 1038, 27-38.

Shock, C.C., Stephen, W.P., Cairo, V., Stieber, T.D., \& Saunders, M. (1989). Irrigation, insect population, and disease management for alfalfa seed production. Oregon State University Agricultural Experiment Station, Special Report 844, 16-21. 
Solanki, R.M., \& Patel, R.G, (2000). Response of lucerne to different moisture regimes. Phosphate levels and sowing methods. Indian Journal Agricultural Research, 34, 160-163.

Tufenkci, S., Erman, M., \& Sonmez, F. (2006). Effect of nitrogen application and Rhizobium inoculation on the yield and nutrient uptake in lucerne (Medicago sativa). Bulletin of Pure and Applied Sciences-Botany, 25, 1.

Vasileva, V. (2010). Effect of mineral nitrogen fertilizing on nodulation of lucerne for seeds in conditions of water deficiency stress. Journal of Mountain Agriculture on the Balkans, 4, 950-960.

Vasileva, V., Kostov, O., \& Vasilev, E. (2006). Development of lucerne (Medicago sativa L.) treated with mineral fertilizer and manure at optimal and water deficit conditions. Comm. Appl. Biol. Sci. Ghent University, 4, 5-17.

Werner, D., \& Newton, W.E. (2005). Soil stress factors influencing symbiotic nitrogen fixation. In: Nitrogen Fixation in Agriculture, Forestry, Ecology, and the Environment. Series: Nitrogen Fixation: Origins, Applications, and Research Progress. Springer, pp. 89-102.

Zahran, H. H. (1999). Rhizobium-legume symbiosis and nitrogen fixation under severe conditions and in an arid climate. Microbiology Molecular Biology Review, 63, 968-989.

Zahran, H. H. (2001). Rhizobia from wild legumes: diversity, taxonomy, ecology, nitrogen fixation and biotechnology. Journal of Biotechnology, 91, 143-153.

\title{
Akumulacija azota u lucerki (Medicago sativa L.) pri vodnom deficitu
}

\author{
Viliana Vasileva • Emil Vasilev
}

Izvod: U cilju ispitivanja akumulacije azota u suvoj masi nadzemnih i podzemnih delova lucerke (Medicago sativa L.) pri vodnom deficitu, eksperiment u saksijama je izveden u Institutu za krmno bilje u Plevenu, Bugarska. Biljke su uzgajane pod optimalnom obezbeđenošću vodom (75-80\% poljskog vodnog kapaciteta), a desetodnevni stress pri vodnom deficit je simuliran u fazi pupoljaka prekidom dovoda navodnjavanja do smanjenja vlažnosti zemljišta na 37 $40 \%$ vodnog kapaciteta. Primenjeno je mineralno azotno đubrenje (amonijum nitrat) u dozama 40, 80, 120 i $160 \mathrm{mg} \mathrm{N}$ kg-1 zemljišta. Akumulacija azota pri vodnom deficitu u suvoj masi nadzemnih delova je smanjena na $18,0 \%$ a u suvoj masi podzemnih delova na 26,5\%. Mineralno azotno đubrenje doprinelo je lakšem prevazilaženju stresnih uslova pri vodnom deficitu u usevu lucerke.

Ključne reči: akumulacija, azot, deficit vode, đubrenje, lucerka 